\title{
AESTHETIC CATEGORIES “LOVE”, “JOY” AND “FEAR” IN THE PROFESSIONAL ACTIVITY OF A TEACHER
}

\author{
HRYHORIY VASIANOVYCH, GALINA SHEWKUN, KATERYNA LATYSCHEVSKA
}

\begin{abstract}
Different approaches to defining the essence and content of the concepts of "love", "joy" and "fear", their interaction in terms of teaching are analyzed in the article. It is emphasized that the main thing in love is its spiritualization. Only the spirit, the spiritual power, reveals to a man the true, worthy object of love. Love is creativity, openness of the human soul, it is an organic, aesthetic need of a man. This approach is especially important in the system of relations "teacher student; teacher - student". It is proved that the teacher's love for the student must be effective, it is based on trust, mutual assistance, without love pedagogical activity loses its value. An important manifestation of love is the joy of common achievements. Love and joy are related concepts. Joyful hobbies that guide cognition, enter the noosphere of a man, contribute to mental and spiritual growth. Instead, the category of "fear" is defined as an emotion that arises in a situation of threat to the biological or social existence of the individual and is aimed at the source of real or imagined danger. In the article, the concept of "fear" is considered on a Christian basis, and therefore, analyzed as the fear of God and human fear. The need to train specialists in the field of professional and pedagogical activities in the context of solving the outlined problems is emphasized.
\end{abstract}

Keywords: love, joy, fear of God, fear of a man, teacher, professional activity of a teacher.

\section{INTRODUCTION}

Productive professional activity of a teacher is inconceivable without love, which in its manifestation brings him great emotional satisfaction, elation, and joy. The concept of "love" is quite broad. It is filled with different meanings, because the objects and subjects of love can be parents and children, students and teachers, artists and their works, natural phenomena, and finally, and different things. The analysis of the category of "love" is usually carried out in different planes: philosophical, ethical, cultural, psychological and pedagogical, as well as - aesthetic.

With all the different approaches to the analysis of the object of love, its unconditional spiritualization is unambiguous. If we consider love itself, regardless of spiritualization, it can be easily replaced by blind passion, instinct, lust, sex, and so on. At the aesthetic and personal level, love is characterized by creativity and openness of a soul, it is the ability to unite and identify with the chosen person. The object of the love of the Master, Jesus Christ, was all mankind, and He undoubtedly gave His life for us, for the human race. Jesus Christ taught to love one's neighbor as oneself, because only through love is the human soul purified and renewed, because we are all children of God. 
True love is the connection of the spirit and soul of one person with another. On this occasion, Hryhoriy Skovoroda wrote in a letter to his favorite student, Mykhailo Kovalinsky: "Good love is one that is true, strong and eternal. Love can in no way be eternal and lasting if it is generated by perishable things, that is, wealth, and so on. Strong and eternal love arises from the kinship of eternal souls, which are strengthened by their virtue and are not chewed. For just as a rotten tree does not stick to another rotten tree, so friendship does not arise between unworthy people. Therefore, if my love is dear to you, do not be afraid that it will end. Because as long as you respect virtue, love grows, just as a tree grows imperceptibly over the years and becomes stronger than death" [6, p. 158].

\section{ANALYSIS AND Discussion}

In the history of pedagogical thought there is not such a teacher-scientist who would not address the problem of love in the system "teacher - student". In particular, J. Comenius in his "Great Didactics" concluded that schools can be real workshops of humanity, "if teachers are friendly and kind, will not push children away with their harsh attitude, but will attract them with their parental affection, manners and words; if teachers advise the sciences to which they turn, from the advantage, attractiveness and ease [3, Vol. 1, p. 342]. So, J. Comenius emphasized, if there is love in the school, there will be less quarrels, all kinds of quarrels, rudeness, if the teacher meets his high purpose, then in such a school there will be lighter, filled with joy, harmony, and peace. An uneducated teacher who does not like children, "is a shadow without a body, a cloud without rain, a spring without water, a lamp without light, and therefore an empty place. Let him be ashamed! " [3, Vol. 2, p. 125].

The idea of sincere love of teachers for students was consistently defended by K. Ushynsky, who in his famous work "Man as a subject of education" wrote that "... the need for grace and love does not follow from the subject of love, but is an organic need of man..." [7, p. 290]. According to the scientist, not only parents but also teachers should be called to show the child sincere attention, care, kindness, kindness; provide her with the necessary help, advice, support; to inspire trust and understanding in her, etc. Extremely interesting and correct in this sense is the opinion of the famous philosopher and teacher V. Zenkivsky, who linked the love of the teacher to the student with the need for active knowledge of the world and the world of the child. He believed that cognition is not only a mental activity of the individual, it is a manifestation of his moral, spiritual and aesthetic needs. "The love that underlies cognitive activity," wrote the thinker, "is the same love that connects the world into a single whole, which illuminates from within some parts of being for others. To know everything means, in the end, to embrace everything with love" [1, p. 42].

Knowledge of the child's world is a real joy for the teacher, is the source that fills the meaning of his mental, aesthetic, professional activities, because it is in this way possible holistic transformation of man and the world in the direction of good and beauty. Moreover, in love-joy the supernatural ability of the person to go beyond itself is realized, and then the child becomes capable to feel the present symphony of soul and spirit. The teacher's love for the student can find various manifestations, one of which is attention and respect. Of course, not only a child, but also an adult needs attention, but a child especially needs it, at least because it provides him with reliability, security, peace, mental balance. Instead, the teacher can show his attention to the student in different ways: formally, when he, for example, says without emotion: "I'm listening to you...", or emotionally address the student so that he will understand the tone of voice, facial expressions: the teacher is interested in listening to me and helping. In such a process of live interaction it is vital to establish contact, which will understand what changes have occurred or are occurring in the soul of the student, what is interesting and uninteresting, what are the reasons that motivate him to certain actions. Without proper attention of the teacher to the student, the latter eventually loses self-confidence, he has an inner anxiety, as if "causeless" irritability, there is an inhibition of intellectual and even physical development, everything seems useless and ugly.

Psychologists have proven that children who are deprived of their parents' attention especially suffer from teacher inattention. The same student who felt the teacher's attention with his heart not only experiences moments of joy and confidence, but also sends these impulses of joy, satisfaction to his 
teacher, with all his being testifies that he loves his mentor, that he needs him. The teacher's love for the student occurs in the process of directing the actions of the latter. To lead a student does not mean to impose one's thoughts rudely on him, to teach him insistently, or to moralize him too much. In this case, the result of education may be the exact opposite of the goal. Skillful guidance of the actions of the pupil involves, above all, the rejection of dictation and strict order. The child should be led through life with a kind word, kindness, own example. Today, when the issue of socialization is so acute, it is important to model children's social skills with aesthetic forms, methods, tools, as well as the best art samples, taking into account the aesthetic needs of the child. It is under such conditions that the teacher is able to feel and understand the emotional state of the child, to perceive it as it is. He has the soul to "catch" not so much a fact that the student reports, but his attitude to this fact, to understand what the student wants: support in assessing this fact or denial of his thoughts and beliefs. In any case, the child should be made to understand that I, the teacher - see, perceive you, do not remain indifferent to your problems, moreover, I approve that these problems are interesting to you. Approval is a very important stimulus for mutual understanding and spiritual growth of the student's personality. A wise teacher who loves his students knows how to help them get rid of the feeling of certain losses. These losses can be for the child or real, or pretended, and sometimes pretended losses can make more sense to her than real. In any case, the teacher cannot be indifferent to emotionally significant events in the life of the student. For example, for a teenager betrayal, the loss of first love can even be a motivating factor for suicide, at best, for mental disorders, emotional breakdowns. From the aesthetic point of view, this can be qualified as tragedy, acute mental suffering, as a loss of meaning in life. In such a situation, the teacher must be able to help the pupil to "bury" his loss as painlessly as possible. And this can be facilitated by the involvement of works of art, a tactful story that life is driven by contradictions, that in life there are not only gains but also losses that must be worthily experienced. The main thing is that in such stories there is sincerity, trust, and truth.

The emotional aesthetic palette of the child should be dominated by bright, joyful colors. And these paints should be given to her by the teacher. The spiritual support of the student by the teacher is an important indicator of his love, faith, optimism. It does not allow to "block" the self-development of the pupil, his creative potential. Support should be so aesthetically pleasing that not the educator, but the pupil becomes the main actor in the creation of the beautiful and sublime. In this sense, belief is formed that the child is able to overcome obstacles, to assert itself by real actions. On the other hand, here the emotional need of the person in trust is realized, the impulse of openness to others works. When young people are in a lofty state of love, they swear to trust each other, never to betray each other. Still, it is worth noting that a wonderful sense of trust between teacher and student does not arise immediately, and sometimes may not occur at all. Only small children who have not yet learned life are trusting in everything. But as you grow older, you accumulate not only positive but also negative experiences of human relationships between people. Insincerity, injustice, failure to keep these promises, etc. have a particularly negative effect on the establishment of love and trust.

The aesthetics of relations between people is always different, unique, inimitable, but it is unconditional that the degree of trust of a person depends on his knowledge, life experience, a certain socio-cultural, educational environment [9]. People, adults and children, always suffer from a lack of trust and expression of love. Another important manifestation of love and joy is the joint achievements of teachers and students. Among teachers you can often hear the following phrase: "Nothing is more successful than success." And indeed: for the student and his teacher - it is a great joy, even exaltation, it is progress to new achievements and peaks. This topical issue is thoroughly described in the textbook "Pedagogy of Success" [5]. Textbook authors: O. Romanovsky, V. Mykhailychenko, L. Gren convincingly prove that thanks to the achievements the student gains confidence in his abilities, he wants to go further on the path of cognition and self-knowledge. Instead, young teachers sometimes make mistakes when comparing the progress of one child with another. In Soviet times, this situation was almost the norm, and instead of developing the child, making her happy, joyful, she depressed her. That is why we consider pedagogically correct the situation when the teacher compares the successes, achievements of not one student with another, but only with himself. Approvals like: "Yesterday you 
did not know how to solve this problem, and today you have solved it so skillfully!", will undoubtedly contribute to the student's desire to achieve new academic success. Undoubtedly, the greatest achievement for a child is overcoming their shortcomings, acquiring new positive skills, qualities, as well as affirming their actions in self-analysis, and at the same time do not forget about the act of selfapproval.

The teacher shows love for the child most productively when he has a good spiritual, physical, moral and psychological well-being, when he is properly well-off, not overburdened with everyday affairs. The situation today shows something completely different: all these components are "eaten" a lot by the routine work of the teacher, and this in turn cannot but have a negative impact on students. There is little or no joy in everyday life, in such conditions it is difficult for a teacher to switch his consciousness to the beautiful and sublime, to fantasy and dreams, the prospects for further activity. Forces are wasted on overcoming misfortunes, some trivial life adventures, and this often leads to depression, lack of energy for self-improvement. The teacher must still learn to enjoy the wonderful moments of life and teach it to students.

Thus, man is endowed with the high gift of the Lord - love. Love in the professional activity of a teacher is his highest, spiritual need. It is not just a feeling, it is all the energy aimed at making him and his students grow and develop in all respects: spiritual, physical, mental, moral and aesthetic. Love is our most healing, most beneficial life resource. Man seeks love, but often he is afraid of losing it, then comes fear.

The category "fear" is defined as "an emotion that arises in a situation of threat to the biological or social existence of the individual and is aimed at the source of real or imagined danger" [4, p. 386].

This definition emphasizes two aspects in terms of threats: biological and social. Like any other, such a concept has a right to exist. Instead, we believe that it lacks the spiritual and aesthetic aspect, which is the most significant. The spiritual-aesthetic aspect directs our consciousness to realize the importance of the Spirit and to overcome fear. The poet B. Pasternak has repeatedly emphasized in this regard: "A lot of smart people - not enough spirit"! Thus, our understanding of the category of "fear" is closely related to the Christian. Christianity traditionally considers the essence and meaning of the concept of "fear" on two main levels: a) the fear of God and b) the fear of man.

Fear of God. It is interpreted as the love of a man who lives by the measure of conscience, dignity and honor, sincerity, patriotism, truthfulness before the face of God, and therefore is constantly in denial with all that is ugly, ugly, false, treacherous. Such fear of God is meaningful and integral love, which is able to protect everything worthy, good, beautiful and sublime, such fear is freedom. It is this aspect of the problem drew the attention of G. Hegel, who wrote in the "Philosophy of Religion": "Fear of the forces of nature, the sun, thunderstorms, etc. this is not the fear we call religious, because religious fear is contained in freedom. Fear of God is something completely different from fear of the power of nature. It is often said that fear is the beginning of wisdom; such fear cannot be contained in direct religion. It arises in a person only when he knows his weakness in his individual existence, when his loneliness trembles in him and he realizes in himself the abstraction that will make him a free spirit" [2, p. 433]. M. Berdyaev, V. Zenkivsky, I. Ilyin, S. Kierkegaard, T. Prokopovych, H. Skovoroda, K. Ushynsky, P. Yurkevych, and others held the same opinion. At the same time, these philosophers and educators did not deny such a concept as "human fear". Let's turn to its essence.

Human fear. It has various characteristics, including anxiety; surprise; danger; fear; fright; hatred; shame; hope; horror; despair, repentance, etc. In particular, K. Ushynsky, after deeply analyzing these two levels of fear, came to the conclusion about their relationship and interaction. Of course, the thinker, teacher was most interested in the manifestation of human fear in the education system, during the implementation of the educational process. Giving priority to the fear of God and critical of those teachers who distort the use of human fear in the education and upbringing of children, K. Ushynsky wrote: "The pedagogical effect of fear is too questionable, and if it can be used, it is very careful, always bearing in mind that courage is the vital energy of the soul. The biblical phrase "The fear of God is the beginning of wisdom," so loved by educators and mentors, the hunters of the cheap means of instilling fear, has a deep meaning that is seldom understood by those who often use the phrase. They will not 
think that this is not about any fear that is the beginning of wisdom, but only the fear of God. If a person reaches the moral height that fears only one God, it means that he is afraid of one conscience and nothing else in the world is afraid" [8, p. 363]. And then the scientist if asked and gave an answer to his question: "Whether this conscience remains in its natural state, or whether it is revealed by the teachings of Revelation in any case, it is for man the voice of God, and if man, not listening to any threats and temptations of the world, begins to listen carefully only to this voice, will open in it a source of wisdom. But how ugly this biblical expression is abused by various lovers of frightening children! They hide their inability to control their anger, an inability that should remove them from the list of educators, and inspire them not the fear of God, but the fear of the teacher, from which lies, pretense, cunning, cowardice, slavery, weakness, meanness of the soul are born, not wisdom" [8, p. 363].

In addition, K. Ushynsky argued that there is instinctive (natural) and mental fear. The first degree of mental fear has much in common with amazement, but is significantly different from it. To the surprise of the scientist attributed an unexpected phenomenon for us only to the mental process. In fear, a person does not yet know how the new phenomenon will affect his life aspirations, hence the mental anxiety that corresponds to the mental or doubt. If there is no doubt that the new phenomenon is an obstacle to our lives, then we have either an urge to overcome the obstacle, or if the obstacle is beyond our power, we experience a second degree of fear. The highest degree of fear is when a person realizes the imminent danger to his life or the lives of loved ones, this is called horror. It usually leads a person to despair, hopelessness. Psychologists have clearly proven that in a situation where a teacher threatens and intimidates a child, he mostly remembers the distorted face of his mentor, not what he says. It is much easier to intimidate a child than to make him or her happy, joyful, and optimistic. Finally, the teacher should remember well: it is easier for a frightened child to forget what he or she knows than to learn and remember why he or she is taught by force. After all, fear depresses, cripples the strength of the soul.

Not only at the level of law, but also ethics, aesthetics, the teacher must act in such a way as to give the pupil hope, to help him overcome his secrecy (so-called "hermeticism"), fear. At one time Aristotle, followed by R. Descartes, B. Spinoza and others. philosophers, educators denied the relationship between feelings of fear and hope, they believed that these concepts are just the opposite. In our opinion, this is a misconception, and a bad teacher who does not find the spirit, strength of will and love, so that in the most difficult situation, full of real risk, not to assert his pupil in hope and faith, the possibility of overcoming fear.

Thus, the student must feel free in their actions, freedom in his work, study is an effective means of personal development [11]. In the context of our study, the study of the best world experience, the system of socio-pedagogical education of future specialists, where the functional approach is usually dominant, is to prepare for certain activities, narrow specializations of teachers, the dominance of practice-oriented learning [10].

\section{CONCLUSIONS}

Based on the above, we can draw the following conclusions:

1. The problem of love, joy in the professional activity of the teacher remains relevant and requires further research in its moral, aesthetic, spiritual aspect.

2. The teacher in his/her activity must dialectically, intelligently combine the fear of God and the fear of man, giving, of course, priority to the former, which emphasizes the conscience of a man, its virtue. 


\section{REFERENCES}

[1] Vasianovych H.P., Onishchenko V.D. Noology of personality. A textbook for students and teachers of humanities. Spolom, Lviv, 2012. (in Ukrainian)

[2] Hegel G. Philosophy of religion: in 2 volumes. Vol. 1. (Ed.) Gulyga A.V. Thought, Moscow, 1976. (in Russian)

[3] Comenius Ya.A. Selected pedagogical works: in 2 volumes. (Ed.) Piskunova A.I., and others. Pedagogy, Moscow, 1982. (in Russian)

[4] Petrovsky A., Yaroshevsky M. (Eds.) Psychology. Dictionary. Politizdat, Moscow, 1990. (in Russian)

[5] Romanovsky O.G., Mykhailychenko V.Ye, Gren L.M. Pedagogy of success. NTU "KhPI", Kharkiv, 2011.

[6] Skovoroda H.S. Garden of songs: Selected works. (Trans. Zerov M.K., Pelekh P.M., Shevchuk V.O.) Veselka, Kyiv, 1983. (in Ukrainian)

[7] Ushynsky K.D. Man as a subject of education. An attempt at pedagogical anthropology. Works in 6 volumes, Vol.4. Soviet School, Kyiv, 1952. (in Ukrainian)

[8] Ushynsky K.D. Man as a subject of education: Experience of pedagogical anthropology. Moscow: FAIR-PRESS, 2004. (in Russian)

[9] Mazur P., Kondur O., Budnyk O., Nikolaesku I., Parkulab O., Lazarovych N., Grebeniuk N. Artistic and aesthetic preferences of adolescents in Ukraine and Poland. Magazine Inclusions, 7 (Especial) (2020), 593607. Available at: https://revistainclusiones.org/gallery/45\%20VOL\%207\%20NUM \%20Espacio\%20y\%20Tiempo\%20en\%20el\%20Siglo\%20XXI.pdf.

[10] Budnyk O., Nikolaesku I., Atroshchenko T., Shevchenko A., Chinchoy A., Yatsyna S., Zobenko N. Professional training of teachers for social and pedagogical activity: progressive world practices. Volume Inclusions, 8 (Special / Energy Number) (2021), 20-31.

[11] Vasianovych H., Budnyk O. The Category of freedom in the written heritage of John Amos Comenius and Hryhoriy Skovoroda. Advanced Education, 7 (2017), 85-89. doi: 10.20535/2410-8286.93517

Address Hryhoriy Vasianovych, Kateryna Latyschevska, Lviv State University of Life Safety, 35 Kleparivska St., Lviv 79000, Ukraine,

Galina Shewkun, Lviv State Hetman Petro Sahaidachnyi National Ground Forces Academy, 32

Heroiv Maidanu St., Lviv 79012, Ukraine.

E-mail: wasianowych@ukr.net; latysevska93@gmail.com; gshevkun@gmail.com.

Received: 10.02.2021; revised: 09.03.2021.

Васянович Григорій, Шевкун Галина, Латишевська Катерина. Естетичні категорії “дюбов", "радість" і "страх" у професійній діяльності педагога. Журнал Прикарпатського університету імені Василя Стефаника, 8 (1) (2021), 17-23.

У статті аналізуються різні підходи щодо визначення сутності і змісту понять “дюбов", "радість" і “страх", їх взаємодії в аспекті педагогічної діяльності. Акцентовано на тому, що в дюбові головним є ії одухотворення. Аише дух, духовна сила відкриває людині справжній, гідний предмет июбові. Аюбов - це творчість, відкритість дюдської душі, вона є органічною, естетичною потребою людини. Такий підхід є особливо важдивим у системі відносин «учитель - учень; викдадач - студент». Доводиться, що любов учителя до учня має бути дієвою, вона будується на довірі, взаємодопомозі, без любові педагогічна діяльність втрачає свою вартість. Важдивим виявом дюбові є радість від спільних досягнень. Яюбов і радість - споріднені поняття. Радісні захоплення, що керують пізнанням, входять в ноосферу людини, сприяють їі душевно-духовному зростанню. Натомість категорія "страх" визначається як емоція, що виникає в ситуації загрози біологічному або соціальному існуванню 
індивіда і спрямована на джерело реальної або удаваної небезпеки. У статті поняття “страх" розглядається на християнських засадах, а тому аналізуеться як страх Божий і страх людський.

Кдючові слова: любов, радість, страх Божий, страх людський, педагог, професійна діяльність педагога. 